\title{
DEVELOPMENT OF AN ANALYTICAL METHOD FOR THE DETERMINATION OF LEAD BASED ON LOCAL SURFACE PLASMON RESONANCE OF SILVER NANOPARTICLES
}

\author{
Hamed Azimi ${ }^{a}$, Seyyed Hamid Ahmadi ${ }^{b, *,(\odot), ~ M o h a m m a d r e z a ~ M a n a f i a ~, ~ S y e d ~ H u s a i n ~ H a s h e m i ~ M o u s a v i ~ a n d ~ M o s t a f a ~ N a j a f i ~}$ \\ aDepartment of Applied Chemistry, Faculty of Science, South Tehran Branch, Islamic Azad University, Tehran, Iran \\ bDepartment of Environmental Analytical Chemistry, Faculty of clean Technologies, Chemistry and Chemical Engineering Research \\ Center of Iran, 14335-186, Tehran, Iran \\ 'Department of Chemistry, Faculty of Science, Imam Hossein University, Tehran, Iran
}

Recebido em 12/04/2019; aceito em 12/03/2020; publicado na web em 20/04/2020

\begin{abstract}
Lead is environmental pollutant that even in low trace is harmful for human health and wildlife. In this study we presented a colorimetric method for determination of $\mathrm{Pb}^{2+}$ in water by aggregation of silver nanoparticles capped citrate in the presence of deferoxamine as chelating agent. Silver nanoparticles were prepared by reduction of $\mathrm{AgNO}_{3}$ with $\mathrm{NaBH}_{4}$. In the presence of $\mathrm{Pb}^{2+}$, mixture of silver nanoparticles capped citrate and deferoxamine aggregated and color of solution changed from light yellow to violet that depends on $\mathrm{Pb}^{2+}$ concentration. As a result of aggregation, local surface plasmon resonance (LSPR) band of silver nanoparticles around $440 \mathrm{~nm}$ decreases and a new band appears at $580 \mathrm{~nm}$ that depend on $\mathrm{Pb}^{2+}$ concentration. Under optimized conditions, linear relation of concentration of $\mathrm{Pb}^{2+}$ and absorbance ratio $\left(\mathrm{A}_{580} / \mathrm{A}_{440}\right)$, was from 0.19 to $1.29 \mu \mathrm{mol} \mathrm{L}^{-1}$ and limit of detection of $0.056 \mu \mathrm{mol} \mathrm{L}{ }^{-1}$ was found. Control experiments with the addition of 10 other metal ions $\left(\mathrm{Ni}^{2+}, \mathrm{Cu}^{2+}, \mathrm{Ca}^{2+}, \mathrm{Al}^{3+}, \mathrm{Co}^{2+}, \mathrm{K}^{+}, \mathrm{Ba}^{2+}, \mathrm{Zn}^{2+}\right.$, $\mathrm{Mg}^{2+}, \mathrm{Hg}^{2+}$ ) did not result in a distinct change in the color or in the absorption spectra. This approach was successfully tested for determination of $\mathrm{Pb}^{2+}$ in well and tap water.
\end{abstract}

Keywords: silver nanoparticles; colorimetric analysis; lead; deferoxamine; aggregation.

\section{INTRODUCTION}

Heavy metals are generally described as metals with high densities, atomic weights or atomic numbers. Numerous applications of heavy metals in industry, medicine, agriculture, etc., caused concerning of their effects in health and safety in environment. Although heavy metals exist in all over the earth, most environmental contamination carried out in the mining and industrial producing. Environmental contamination by heavy metals also occurs by metal corrosion, atmospheric deposition and soil erosion of metal ions. Some of heavy metals like $\mathrm{Fe}, \mathrm{Mn}, \mathrm{Cu}$ and $\mathrm{Zn}$ considered as essential nutrients and required in biochemical and physiological performance. Other heavy metals like $\mathrm{Pb}, \mathrm{Cd}, \mathrm{Hg}$ and As considered as metals that have no essential biochemical and physiological roles and some of them have toxicity and harmful for human nature, therefore determination of these heavy metals in environment is necessary. ${ }^{1}$

Several of high sensitivity methods such as graphite furnace atomic absorption spectrometry, ${ }^{2}$ electrothermal vaporization inductively coupled plasma mass spectrometry (ETV-ICP-MS), ${ }^{3}$ solid-phase microextraction-gas chromatography-atomic emission detection (SPME-GC-AED), ${ }^{4}$ square wave anodic stripping voltammetry (SWASV) ${ }^{5}$ have been developed for the determination of $\mathrm{Pb}^{2+}$. However, these methods need to time consuming, high price and complicated instruments, thus it is necessary to develop a new method for determination of $\mathrm{Pb}^{2+}$ that fast, low price and there is no need to high price instruments for assay.

Local surface plasmon resonance (LSPR) is a nanosize phenomenon that attracted attention in recent years. This phenomenon can create strong absorption spectra that using for detection of many of chemical and biological samples. ${ }^{6}$ Noble metals like gold and silver have free electrons, when a noble metal in form of nanoparticles, affected by the irradiation of light, free electrons of nanoparticles

*e-mail: ahmadi@ccerci.ac.ir collectively oscillate at a resonant frequency in a phenomenon called surface plasmon resonance and when a noble metal nanoparticle affected under radiation of light, this phenomenon can create sharp absorption spectra. ${ }^{7}$

Local surface plasmon resonance is a powerful method for determination of chemical and biological analytes in the environmental samples. In the past decade, silver plasmonic nanostructures used for determination of metals like $\mathrm{Ba}^{2+}, \mathrm{Mn}^{2+}, \mathrm{Fe}^{3+}, \mathrm{Co}^{2+}, \mathrm{Ni}^{2+}, \mathrm{Cd}^{2+}, \mathrm{Hg}^{2+}$, $\mathrm{Cu}^{2+}$ and $\mathrm{Cr}^{3+}$. ${ }^{-16}$ These experiments are based to plasmon resonance wavelength changes of silver nanoparticles as aggregation that takes place due to interaction between nanoparticles with samples.

The goal of this work is development of a simple and low cost method for determination of $\mathrm{Pb}^{2+}$ in water by silver nanoparticles. We optimized effective factors in the assay like concentration of chelating agent, ionic strength, $\mathrm{pH}$ and concentration of stabilizer agent. Proposed method was successfully applied for the determination of $\mathrm{Pb}^{2+}$ in two real water samples.

\section{EXPERIMENTAL}

\section{Chemical and reagents}

Sodium borohydride $\left(\mathrm{NaBH}_{4}\right)$, silver nitrate $\left(\mathrm{AgNO}_{3}\right)$, sodium chloride $(\mathrm{NaCl})$, sodium hydroxide $(\mathrm{NaOH})$, hydrochloric acid ( $\mathrm{HCl} 37 \%)$, tri sodium citrate $\left(\mathrm{Na}_{3} \mathrm{C}_{6} \mathrm{H}_{5} \mathrm{O}_{7}\right)$ and lead (II) acetate $\left(\mathrm{PbC}_{4} \mathrm{H}_{6} \mathrm{O}_{4} \cdot 3 \mathrm{H}_{2} \mathrm{O}\right)$ were purchased from Merck. Deferoxamine mesylate $\left(\mathrm{C}_{26} \mathrm{H}_{52} \mathrm{~N}_{6} \mathrm{O}_{11} \mathrm{~S}\right)$ was obtained from Sigma-Aldrich. Stock solutions of deferoxamine mesylate and $\mathrm{Pb}^{2+}$ were prepared in distilled water. All different salts were purchased from Merck.

\section{Preparation of silver nanoparticles}

Silver nanoparticles were synthesized by the reduction of $\mathrm{AgNO}_{3}$ with $\mathrm{NaBH}_{4}$. Under vigorous magnetic stirring, $0.012 \mathrm{~g} \mathrm{NaBH}_{4}$ 
was added quickly to $100 \mathrm{~mL}$ aqueous solution of $\mathrm{AgNO}_{3}$ with concentration of $0.1 \mathrm{mmol} \mathrm{L}^{-1}$, producing a light yellow colored solution. Finally, the prepared AgNPs solution was stored at $4{ }^{\circ} \mathrm{C}$ in darkness before use. ${ }^{17}$

\section{Apparatus}

UV-Vis absorbance spectra were acquired on a UV-Vis spectrophotometer with a $1.0 \mathrm{~cm}$ quartz cell from 350 to $650 \mathrm{~nm}$ (PG T80 ${ }^{+}$, PG instruments, United Kingdom). Measurements of $\mathrm{pH}$ carried out by 827 Metrohm pH Meter (Metrohm AG, Switzerland). Size distributions of the particles were done in specific temperature with dynamic light scattering device (Horiba Sz-100, Horiba LTD, Japan). Transmission electron microscopy (TEM) was employed for recording the morphology and size of the nanoparticles (Philips CM30, Netherlands). Inductively coupled plasma-optical emission spectrometer (730-ES, Varian, USA) was used for obtaining ICP data.

\section{Colorimetric detection of $\mathbf{P b}^{2+}$}

For colorimetric of $\mathrm{Pb}^{2+}, 3.3 \mathrm{~mL}$ silver nanoparticles, $50 \mu \mathrm{L}$ deferoxamine $\left(0.0001 \mathrm{~mol} \mathrm{~L}^{-1}\right), 250 \mu \mathrm{L}$ trisodium citrate $\left(0.1 \mathrm{~mol} \mathrm{~L}^{-1}\right)$, and $1.5 \mathrm{~mL} \mathrm{NaCl}\left(0.1 \mathrm{~mol} \mathrm{~L}^{-1}\right)$ were added in volumetric flask and then different amounts of $\mathrm{Pb}^{2+}$ were added to the solution, consequently an appropriate distilled water were added to reach a final volume of $10 \mathrm{~mL}$. Finally, this solution was transferred to the spectrometric cell for measuring absorbance.

\section{Real sample analysis}

To investigate ability of this method for determination of
$\mathrm{Pb}^{2+}$ in water samples, detection of $\mathrm{Pb}^{2+}$ was carried out in two different water samples, consisting of well and tap water. $160 \mu \mathrm{L}$ of $0.001 \mathrm{~mol} \mathrm{~L}^{-1} \mathrm{~Pb}^{2+}$ spiked to $1 \mathrm{~mL}$ water then 25 and $37.5 \mu \mathrm{L}$ from prepared sample individually added to mixture of silver nanoparticles and $\mathrm{NaCl}$ and trisodium citrate.

\section{RESULTS AND DISCUSSION}

\section{Mechanism of assay}

Preliminary experiments with silver nanoparticles were performed to reach the optimal conditions and improving sensitivity of the assay for $\mathrm{Pb}^{2+}$ determination in environmental water samples. The effect of silver nanoparticles, deferoxamine, trisodium citrate and sodium chloride concentrations, $\mathrm{pH}$ and reaction time were studied.

The basis of $\mathrm{Pb}^{2+}$ determination is illustrated in the Scheme 1. This drug used to treatment of patients that suffering $\beta$-thalassemia for ability of this drug to create strong complexes with heavy metals. When deferoxamine was added to the solution contains citrate capped nanoparticles, silver nanoparticles were dispersed and aggregation of silver nanoparticles did not happen but when $\mathrm{Pb}^{2+}$ was added to the solution, due to chelation of $\mathrm{Pb}^{2+}$ with deferoxamine, aggregation of silver nanoparticles happened.

Figure 1 shows absorption spectra of silver nanoparticles demonstrating that silver nanoparticles have a peak around $440 \mathrm{~nm}$ (blue). This Figure also shows when aggregation of silver nanoparticles with adding $\mathrm{Pb}^{2+}$ occurs, characteristic absorbance decreases, and a new broad absorption band appears in around $580 \mathrm{~nm}$ (red). Color of silver nanoparticles changes from light yellow to light violet or violet that depends on $\mathrm{Pb}^{2+}$ concentration. Aggregation of

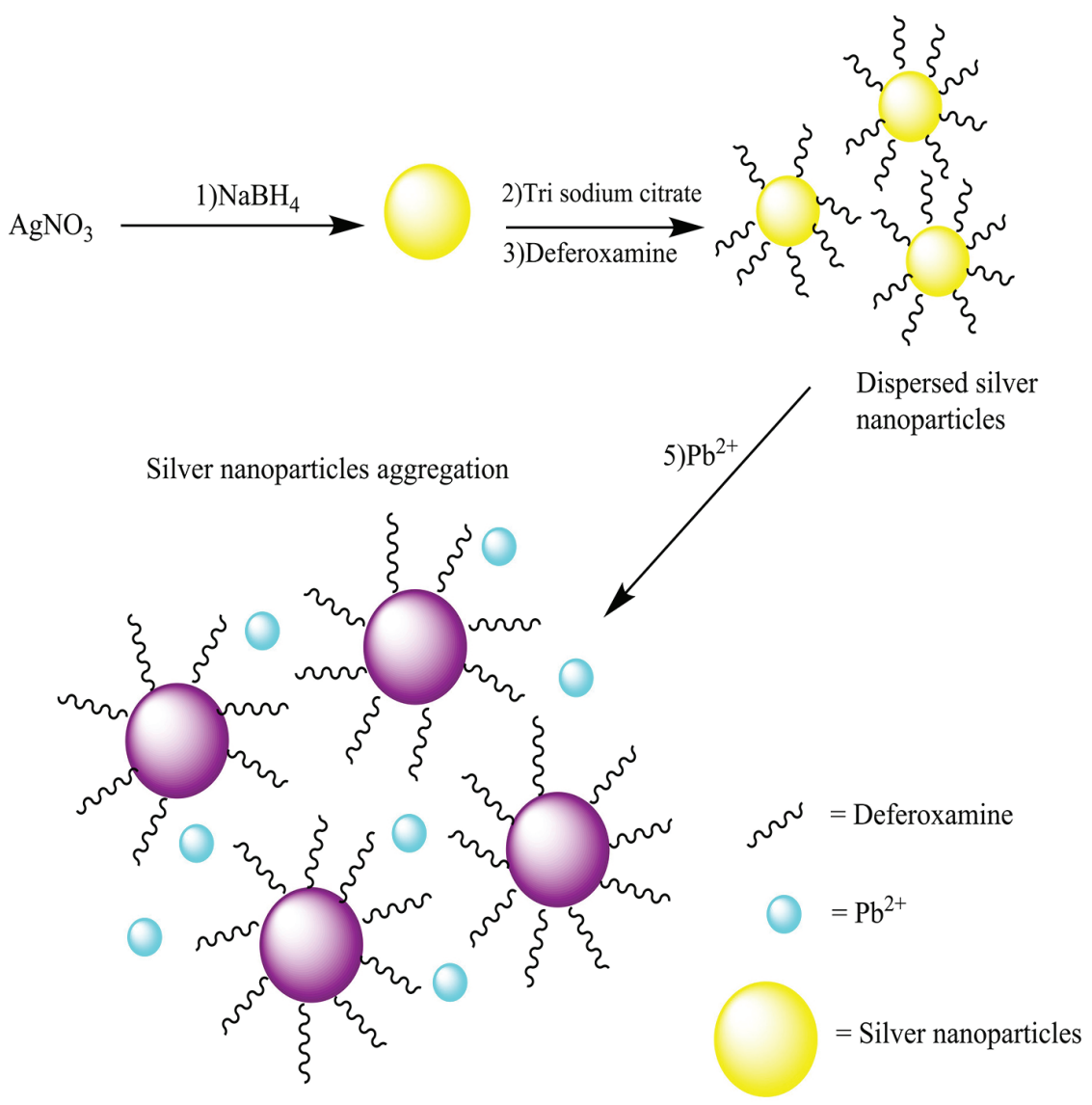


silver nanoparticles with adding $\mathrm{Pb}^{2+}$ and deferoxamine is supported with DLS and TEM images (Figure 1).

\section{Optimization of assay condition}

We studied the effect of reaction time in range of 15-145 seconds in the assay and after 60 seconds there is no change in absorbance ratio and 60 seconds was selected as optimum reaction time for further experiments (Figure 1S).

Effect of deferoxamine concentration in aggregation of silver nanoparticles from 0.5 to $2.5 \mu \mathrm{mol} \mathrm{\textrm {L } ^ { - 1 }}$ was also studied. Ability of silver nanoparticles for aggregation was decreased with increasing deferoxamine concentration (Figure $2 \mathrm{~S}$ ).

Also, the effect of $\mathrm{NaCl}$ concentration on aggregation of silver nanoparticles was explored because ionic strength has a critical role on aggregation of silver nanoparticles. ${ }^{18}$ Aggregation of silver nanoparticles did not take place in low concentration of $\mathrm{NaCl}$ (low ionic strength) but after increasing concentration of $\mathrm{NaCl}$, aggregation carried out in the absence $\mathrm{Pb}^{2+}$ due to sodium chloride can constrict electrical double layer of citrate ions (Figure $3 \mathrm{~S}$ ). $\mathrm{NaCl}$ concentration was studied in range of 5-25 mmol L-1 and $15 \mathrm{mmol} \mathrm{L}^{-1}$ was selected as optimized concentration.

Effect of tri sodium citrate concentration as stabilizer of silver nanoparticles was studied on aggregation of silver nanoparticles. As shown in Figure 4S, concentration of tri sodium citrate studied from 0.5 to $3 \mathrm{mmol} \mathrm{L}^{-1}$ and we observed that with increasing concentration of tri sodium citrate to $2.5 \mathrm{mmol} \mathrm{L}^{-1}$, ratio of absorption was increased and after that, ratio was stabilized, thus $2.5 \mathrm{mmol} \mathrm{L}^{-1}$ of tri sodium citrate was selected as optimum concentration of citrate.

$\mathrm{pH}$ has a crucial effect on aggregation of silver nanoparticles, therefore effect of $\mathrm{pH}$ in the presence of $0.55 \mu \mathrm{mol} \mathrm{L} \mathrm{L}^{-1} \mathrm{~Pb}^{2+}$ was studied in the range of 3-10. In $\mathrm{pH}<3$, due to protonation of citrate molecules, surface charge of the silver nanoparticles was neutralized. In $3<\mathrm{pH}<8$, deferoxamine and citrate molecules were protonated and for this reason, aggregation of silver nanoparticles was increased. In $\mathrm{pH}>8$ tri sodium citrate becomes negative and deferoxamine is neutralized and for this reason, electrostatic attraction between silver nanoparticles decreased and then aggregation of silver nanoparticles was lowered.${ }^{19}$ Consequently, $\mathrm{pH}=8$ was selected as optimized $\mathrm{pH}$ for aggregation of silver nanoparticles in this assay (Figure 5S).

\section{Sensitivity and selectivity of the analytical method}

Colorimetric determination of $\mathrm{Pb}^{2+}$ by deferoxamine under optimum conditions was performed. The calibration curve shows a linear correlation at concentration from 0.19 to $1.29 \mu \mathrm{mol} \mathrm{L}^{-1}$. Limit of detection was calculated $0.056 \mu \mathrm{mol} \mathrm{\textrm {L } ^ { - 1 }}$. Color of the solution of silver nanoparticles is light yellow and when aggregation take place, color of solution firstly is changed to light violet and with increasing concentration of $\mathrm{Pb}^{2+}$ changed to violet (Figure 6S).

\section{Interferences}

By reason to verify selectivity of determination of $\mathrm{Pb}^{2+}$ in water, we studied interfering effect of some metal ions including $\mathrm{Ni}^{2+}, \mathrm{Cu}^{2+}$, $\mathrm{Ca}^{2+}, \mathrm{Al}^{3+}, \mathrm{Co}^{2+}, \mathrm{K}^{+}, \mathrm{Ba}^{2+}, \mathrm{Zn}^{2+}, \mathrm{Mg}^{2+}$ and $\mathrm{Hg}^{2+}$. The metal ions were individually added to silver nanoparticles colloid. Concentration of $\mathrm{Pb}^{2+}$ was $1.29 \mu \mathrm{mol} \mathrm{L}^{-1}$ and concentration of all metal ions considered 50 times higher than $\mathrm{Pb}^{2+}$. As shown in Figure 2, there is no distinct color change and additionally UV-visible absorption features.

\section{Analysis of spiked samples}

To evaluate performance of the colorimetric method, the proposed procedure was applied for the determination of $\mathrm{Pb}^{2+}$ in water samples and two different samples including tap water and well water were studied. Recovery tests were used to evaluate the matrix effects, accuracy and reliability of the method. The different standard amounts of $\mathrm{Pb}^{2+}$ were spiked into the samples and lead concentration was determined at optimum conditions for each sample. The results of study are summarized in Table 1, as can be seen, they indicate the potential of this method for simple and sensitive determination of $\mathrm{Pb}^{2+}$ in real water samples. The results indicate quantitative recoveries in tap and well water (95-111\%). The results were in good agreement with those obtained by ICP OES, demonstrating the practical analytical utility of the method. Also, the relative standard deviations

(B)
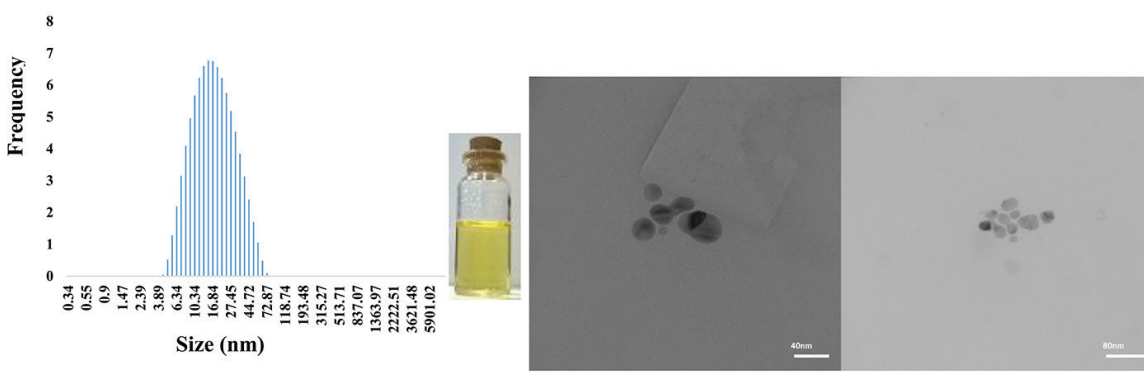

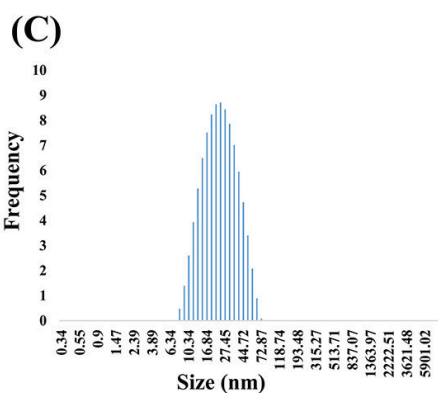

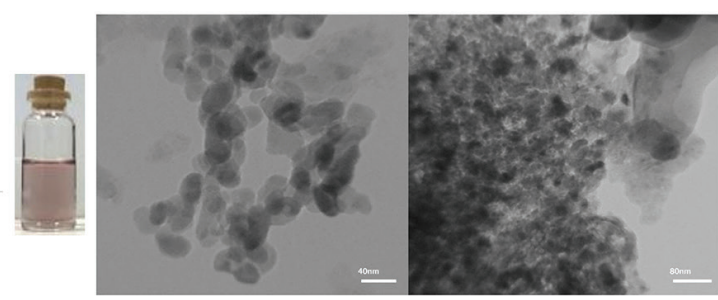

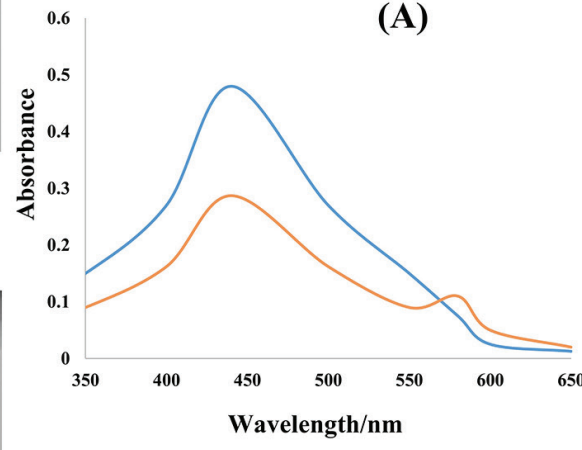

Figure 1. Absorption spectra in absence (blue) and in the presence (red) of $0.55 \mu \mathrm{mol} \mathrm{L} L^{-1} \mathrm{~Pb}^{2+}($ a). TEM images and color of silver nanoparticles and DLS analysis of silver nanoparticles (b) in absence and (c) in the presence of $0.92 \mu \mathrm{mol} \mathrm{L} \mathrm{L}^{-1} \mathrm{~Pb}^{2+}$ 
0.7

0.6

0.5

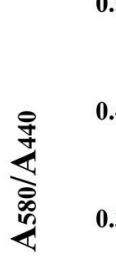

0.3

0.2

0.1

0
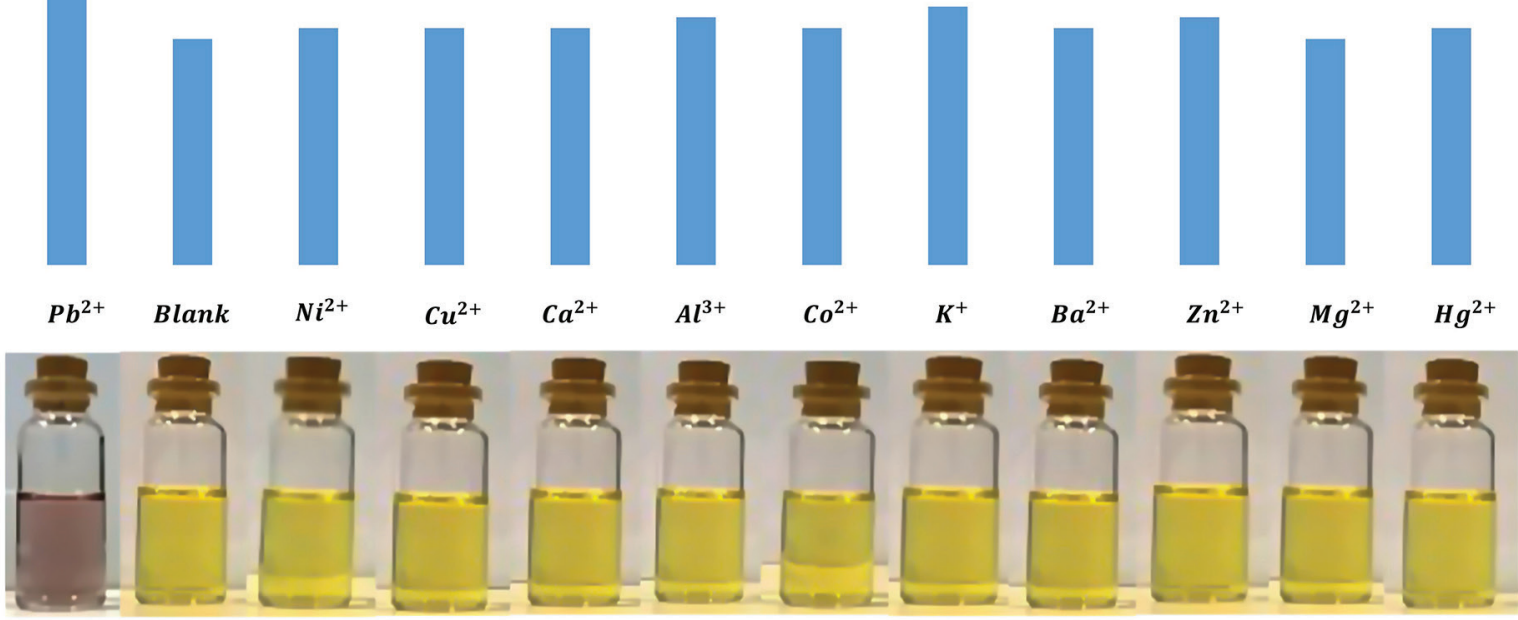

Figure 2. The absorption ratio value $\left(A_{580}\left(A_{440}\right)\right.$ and images of silver nanoparticles in the presence of interferences including $\mathrm{metal}_{\mathrm{ions}}\left(\mathrm{Ni}^{2+}, \mathrm{Cu}^{2+}, \mathrm{Ca}^{2+}, \mathrm{Al}^{3+}\right.$, $\left.\mathrm{Co}^{2+}, \mathrm{K}^{+}, \mathrm{Ba}^{2+}, \mathrm{Zn}^{2+}, \mathrm{Mg}^{2+}, \mathrm{Hg}^{2+}\right)$. Concentration of $\mathrm{Pb}^{2+}$ is $1.29 \mu \mathrm{mol} \mathrm{L} \mathrm{L}^{-1}$ and concentration of all metal ions considered 50 times higher than $\mathrm{Pb}^{2+}$

(RSD) were found to be $<5 \%$ in tap and well water. The intra-day and inter-day precisions of the proposed method were used to evaluate the precision of the method. For this purpose, five similar experiments were carried out for the analysis of samples on the same day and on five consecutive days. The resulted RSDs for the analysis of intraday and inter-day spiked samples were in the range of $1.8-3.1 \%$ and $2.1-4.4 \%$, respectively.

Table 1. Determination of $\mathrm{Pb}^{2+}$ in well and tap water $(\mathrm{n}=5)$

\begin{tabular}{lcccccc}
\hline Samples & $\begin{array}{c}\text { Spiked } \\
\left.(\mu \mathrm{mol} \mathrm{L})^{-1}\right)\end{array}$ & $\begin{array}{c}\text { Found } \\
\left.(\mu \mathrm{mol} \mathrm{L})^{-1}\right)\end{array}$ & $\begin{array}{c}\text { Recovery } \\
(\%)\end{array}$ & $\begin{array}{c}\text { Intraday } \\
\text { RSD }(\%)\end{array}$ & $\begin{array}{c}\text { Interday } \\
\text { RSD }(\%)\end{array}$ & $\begin{array}{c}\text { ICP-OES } \\
\left(\mu \mathrm{mol} \mathrm{L}^{-1}\right)\end{array}$ \\
\hline \multirow{4}{*}{ Well water } & 0 & $\mathrm{ND}$ & - & - & - & $\mathrm{ND}$ \\
& 0.40 & 0.38 & 95 & 3.1 & 3.2 & 0.420 \\
& 0.60 & 0.67 & 111 & 2.3 & 4.4 & 0.608 \\
\hline \multirow{4}{*}{ Tap water } & 0 & $\mathrm{ND}$ & - & - & - & $\mathrm{ND}$ \\
& 0.40 & 0.41 & 103 & 1.9 & 2.1 & 0.415 \\
& 0.60 & 0.64 & 106 & 1.8 & 2.7 & 0.627 \\
\hline
\end{tabular}

$\mathrm{ND}=$ not detected.

\section{Comparison with previous studies}

Our proposed analytical method showed satisfactory due to simplicity, speed, efficiency and no need to sample preconcentration compared with the previous studies as shown in Table 2. It can be successfully applied to determination of lead in tap water samples.

The limit of detection and the linear dynamic range of the proposed method for the lead are comparable with other methods. ${ }^{20-29}$ However, in comparison to the solid phase extraction-colorimetry, LSPR technique is faster.
Table 2. Comparison of figures of merit of the present method with other reported methods for colorimetric determination of $\mathrm{Pb}^{2+}$ in aqueous samples

\begin{tabular}{|c|c|c|c|c|}
\hline Method & $\begin{array}{c}\mathrm{LOD}^{\mathrm{a}} \\
\left(\mu \mathrm{g} \mathrm{L}^{-1}\right)\end{array}$ & $\begin{array}{l}\mathrm{LDR}^{\mathrm{b}} \\
\left(\mu \mathrm{g} \mathrm{L}^{-1}\right)\end{array}$ & Matrix & Ref. \\
\hline Colorimetry $\left(\mathrm{LSPR}^{\mathrm{c}}\right)$ & 5.2 & $10-207$ & Water & 20 \\
\hline Colorimetry $\left(\mathrm{SPE}^{\mathrm{d}}\right)$ & 10 & $20-2500$ & Water & 21 \\
\hline Colorimetry (LSPR) & 0.5 & $5-190$ & Water, Milk & 22 \\
\hline Colorimetry (LSPR) & 4.1 & $12-200$ & Water, Urine & 23 \\
\hline Colorimetry (SPE) & 1.5 & $5-160$ & Water & 24 \\
\hline Colorimetry & 100 & $500-500000$ & Water & 25 \\
\hline Colorimetry (LSPR) & 2.7 & $83-1650$ & Water & 26 \\
\hline Colorimetry (LSPR) & 40 & $100-600$ & Water & 27 \\
\hline Colorimetry (LSPR) & 3.3 & $10-50$ & Water & 28 \\
\hline Colorimetry $\left(\mathrm{KS}^{\mathrm{e}}\right)$ & 0.13 & $0.2-200$ & Water & 29 \\
\hline Colorimetry (LSPR) & 11.6 & $39-267$ & Water & This work \\
\hline
\end{tabular}

${ }^{\mathrm{a}}$ Limit of detection. ${ }^{\mathrm{b}}$ Linear dynamic range. ${ }^{\mathrm{c}}$ Local surface plasmon resonance. ${ }^{\mathrm{d}}$ Solid phase extraction. ${ }^{\mathrm{e}}$ Kinetic spectrometry.

\section{CONCLUSION}

In this assay silver nanoparticles capped with citrate are used for determination of $\mathrm{Pb}^{2+}$ based on silver nanoparticles aggregation. We observed high sensitivity and good linear calibration curve. Under optimized conditions, DLR was from 0.19 to $1.29 \mu \mathrm{mol} \mathrm{L}^{-1}$ and limit of detection was $0.056 \mu \mathrm{mol} \mathrm{L}^{-1}$. The figures of merit obtained are in good agreement with reported colorimetric researches. ${ }^{20-29}$ The main 
advantages of the proposed method are simplicity, sensitivity, low cost, and ease of operation.

\section{ACKNOWLEDGEMENTS}

The authors wish to state their thanks to Islamic Azad University South Tehran Branch, for supporting this work.

\section{REFERENCES}

1. Tchounwou, P. B.; Yedjou, C. G.; Patlolla, A. K.; Sutton, D. J.; Mol. Clin. Environ. Toxicol. 2012, 101, 133.

2. Spudich, T. M.; Herrmann, J. K.; J. Chem. Educ. 2004, 81, 262.

3. Li, L.; Hu, B.; Xia, L.; Jiang, Z.; Talanta 2006, 70, 468.

4. Crnoja, M.; Troyer, C. H.; Rosenberg, E.; Grasserbauer, M.; J. Anal. At. Spectrom. 2001, 16, 1160.

5. Pena, R. C.; Cornejo, L.; Bertottic, M.; Brett, C. M. A.; Anal. Methods 2018, 10, 3624.

6. Mayer, K. M.; Hafner, J. H.; Chem. Rev. 2011, 111, 3828.

7. Lu, X.; Rycenga, M.; Skrabalak, S. E.; Wiley, B.; Xia, Y.; Ann. Rev. Phys. Chem. 2009, 60, 167.

8. Khodaveisi, J.; Haji Shabani, A. M.; Dadfarnia, S.; Moghaddam, M. R.; Hormozi-Nezhad, M. R.; Quim. Nova 2015, 37, 896.

9. Zhou, Y.; Zhao, H.; Li, C.; He, P.; Peng, W.; Yuan, L.; Zeng, L.; He, Y.; Talanta 2012, 97, 331.

10. Zhan, J.; Wen, L.; Miao, F.; Tian, D.; Zhu, X.; Li, H.; New J. Chem. 2012, 36, 656 .
11. Yao, Y.; Tian, D.; Li, H.; ACS Appl. Mater. Interfaces 2010, 2, 684.

12. Shang, Y.; Wu, F.; Qi, L.; J. Nanopart. Res. 2012, 14, 1169.

13. Li, H.; Yao, Y.; Han, C.; Zhan, J.; Chem. Commun. 2009, 32, 4812.

14. Fan, Y.; Liu, Z.; Wang, L.; Zhan, J.; Nanoscale Res. Lett. 2009, 4, 1230.

15. Ratnarathorn, N.; Chailapakul, O.; Henry, C. S.; Dungch, W.; Talanta 2012, 99, 557.

16. Wu, T.; Liu, C.; Tan, K. J.; Hu, P. P.; Huang, C. Z.; Anal. Bioanal. Chem. 2010, 397, 1273.

17. Wu, X.; Xu, Y.; Dong, Y.; Jiang, X.; Zhu, N.; Anal. Methods 2013, 5, 560.

18. Vaishnav, S. K.; Patel, K.; Chandraker J.; Korram, K.; Nagwanshi, R., Ghosh, K. K.; Satnami, M. L.; Spectrochim. Acta, Part A 2017, 179, 155.

19. Badawy, A. M. E.; Luxton, T. P.; Silva, R. G.; Scheckel, K. G.; Suidan, M. T.; Tolaymat, T. M.; Environ. Sci. Technol. 2010, 44, 1260.

20. Ding, N.; Cao, Q.; Zhao, H.; Yang, Y.; Zeng, L.; He, Y.; Xiang, K.; Wang, G.; Sensors 2010, 10, 11144.

21. Caliskan, E.; Tinas, H.; Ozbek, S.; Akman, N.; Anal. Sci. 2017, 33, 387.

22. Ratnarathorn, N.; Chailapakul, O.; Dungchai, W.; Talanta 2015, 132, 613.

23. Xu, H.; Liu, B.; Chen, Y.; Microchim. Acta 2012, 177, 89.

24. Al-Mallah, Z.; Amin, A. S.; J. Ind. Eng. Chem. 2018, 67, 461.

25. Yan, J.; Indra, E. M.; Anal. Chem. 2012, 84, 6122.

26. Qi, L.; Shang, Y.; Wu, F.; Microchim. Acta 2012, 178, 221.

27. Noh, K. C.; Nam, Y. S.; Lee, H. J.; Lee, K. B.; Analyst 2015, 140, 8209.

28. Annadhasan, M.; Muthukumarasamyvel, T.; Sankar Babu, V. R.; Rajendiran, N.; ACS Sustainable Chem. Eng. 2014, 2, 887.

29. Wu, T.; Ma. Z.; Microchim. Acta 2017, 184, 577. 